\title{
Promoting Infrastructural Development Affecting Private Organization Supply Chain Management and Productivity Through PPP, Nigeria
}

\author{
Babatunde Ibibo Ogunbona \\ International Graduate Centre, Hochschule Bremen
}

\begin{abstract}
Modern-day organizations place so much emphasis on its supply chain management. This is a necessity to ensure optimal production is achieved with minimal loss of time and revenue. However, the success of the supply chain is dependent on the infrastructural facilities available in their operating environment which has been provided by the government. In Nigeria, public infrastructural facilities are still at a struggling stage, making it difficult for private firms to depend solely on this infrastructure and seek alternative means. This research has highlighted the importance of private public partnership in developing infrastructure to enhance supply chain management and productivity.
\end{abstract}

Keywords: Supply chain management, Public infrastructure, Productivity, Private public partnership

DOI: $10.7176 / \mathrm{EJBM} / 13-2-02$

Publication date: January $31^{\text {st }} 2021$

\section{Introduction}

The supply chain departments of organizations have begun to adopt zero-tolerance for delayed processes, unnecessary bottle-necks, non- value processes and process flow. The Ultimate goal of supply chain management is ensuring efficient production and timely delivery of finished goods and services to end users within a reasonable time frame. It's imperative to note the supply chain is made up of inventory, Production, warehousing, storage, transportation, information technology and management. All of these factors are interwoven with certain infrastructures available in every economy. A failure of any economic infrastructure has a colossal effect on the supply chain process. However, we have seen only a few private public partnership (PPP) geared towards resolving these infrastructure challenges, leaving businesses opting for palliative measures to cushion the effect of inefficient infrastructure on their operations.

Supply chain management defined by Lambert, Copper \& Pagh (2000) states SCM as the production of goods and services as a combination of processes from production to the final user stage to meet the needs of various end users. The coordination of activities between the suppliers and end consumer, which amounts to delivery of worthy customer advantage at a lower cost in the supply chain process (Christopher, 2016). SCM rides on the back of infrastructure to excel, it can also be viewed as a factor of production, secondly, it can be mirrored as an allotment influencing the citation of private investment or employment (Rietveld, 1989). Fourie (2006) believes economic infrastructure namely roads, highways, rail roads, airports, seaports, electricity, telecommunication, water supply and sanitation promote economic actions. She went on to state Infrastructural 'publicness' features translate to government function, has never been expressly spelt out. We also need to bear in mind that the end game is to ensure productivity is achieved. Tangen (2002) expressly states, "productivity as the relationship between output and input". He further explains that one of the key elements governing economic production is productivity, we can conclude it to be the most vital element. Simultaneously, the most critical resource with a direct effect on a manufacturing company's competitiveness is productivity.

\section{Literature Review}

It's a given that the existent of supply chain management is dependent on the public infrastructure put in place by the government of the society. Supply chain management is made up of various segments which are interwoven with basic infrastructural facilities. Unfortunately, Nigeria is currently struggling with public infrastructural challenges which has made it a herculean task in ensuring the efficiency of supply management functions of various private organization. Adhikary\& Khatun (2017) groups infrastructure into Electricity, Good roads, Transportation and Communication. Mentzer et al. (2001) list some supply chain management element as Warehousing, Logistics, Information systems and for the sake of this research we will be concentrating on these few elements in the table below, whose operation have been impacted by poor public infrastructure in Nigeria.

Table 1: Elements of Supply Chain Management

\begin{tabular}{|l|l|}
\hline Elements of Supply Chain Management & Required Infrastructure \\
\hline Production, Warehousing and Storage & Electricity \\
\hline Logistics & Road \\
\hline Information and Technology & Communication \\
\hline
\end{tabular}


Production

- Electricity Infrastructure

Stainer and Stainer (1997) "believes the term productivity is often ill-defined but, basically, its measurement is that of a prescribed output to the resources consumed". One of the key functions of infrastructure is to encourage output, efficiency, productivity growth and reducing production cost which has received increasing attention from policy makers (Sharma \& Sehgal 2010). Moyo (2013) states power is needed to put machinery into use, but the whole essence is not just the machinery functioning but also ensuring stimulation of labour by ensuring the machines are used optimally by individuals thereby yielding productivity. Olayemi (2012) is opined to believe that manufacturing organizations have their backs against the wall and are left with no other option than to purchase power generator sets due to the irregular power supply in the country to ensure optimal production. Running power generators comes with additional costs such as procurement of petrol and diesel. This cost would lead to an increase in their operating cost and also affect the drive for industrialization in Nigeria. They are left with no option but to seek alternative sources of power and pass on the increase in production cost to the consumers. Urowayino (2020) reported that Manufacturing companies under the aegis of Manufacturers Association of Nigeria (MAN) expended 38 percent of their production cost on energy in 2019.

Warehousing and Storage

- $\quad$ Electricity Infrastructure

Ramaa, Subramanya \& Rangaswamy (2012) advocate that in a supply chain, warehousing plays a very vital role as it serves as a vessel through which materials flow between the supplier and customer. Warehousing or storage facilities for perishable good requires a refer container or cold room temperature. "The cold chain management is to properly control temperature, moisture, environmental conditions and time throughout processes especially in storage, handling and transportation from an upstream to downstream supply chain" (Chaitangjit \& Ongkunaruk, 2019). This is achieved by setting up cooling systems which are powered up with electricity. Users of electricity supply in Nigeria are receiving and paying outrageously high bills despite the inconsistent and unreliable power supply, thereby drawing criticism from the public at large (Ado \& Mallo, 2015). The epileptic power supply in Nigeria had forced many organizations to provide alternate power supply back up at an astronomical cost thereby increasing their production cost which in turn is passed on to the consumer directly or indirectly. This obviously would have an effect on their Earnings interest, taxes, depreciation and amortization. (EBITDA).

Logistics

- Road Infrastructure

Lummus, krumwiede, \& Vokurka, (2001) defines logistics across all boards as a set of activities that encompasses processes such as planning and controlling the movement and storage of goods and services from the manufacturer to the end user, taking into consideration all approved standards and guidelines. Over the past years, in depth study has revealed how transport and logistics affect decision making and government policy (Oyesiku, Somuyiwa and Oduwole, 2020). According to Tseng, Yue \& Taylor (2005), transportation joins all the activities of the supply chain together, thereby making it a prerequisite supply chain function. Unfortunately, road transportation in Nigeria is a challenge due to poor road infrastructure. The road infrastructure in the country has been in a state of moribund ranging from lack of funding, lack of timely and proper maintenance, blocked, collapsed and nonexistent drainage systems which has made logistics challenging and expensive. This has made the movement of raw materials and finished goods a daunting and expensive task with wasted man hours involved in navigating through the deplorable state of roads (Emeasoba and Ogbuefi, 2013).

\section{Information and Technology Infrastructure}

- Communication Infrastructure

Information and Technology Infrastructure also does have an effect on logistics and warehousing. Logistics require IT for vehicle and goods tracking and communication with transport teams while warehousing requires IT for mostly inventory control, and communication between manufacturer and end user of products. Some of the issues that affects communication are lack of broad band coverage areas, poor internet speed and high cost of data. Posu (2006) references that the current state of infrastructure in Africa is below standard and inefficient. Telecommunication services are offered at cut throat prices. Modernization has made this infrastructure more of a necessity for private organizations rather than a luxury, and also a vital tool in supply chain management in a growing and productive economy. "ICT is the backbone of business activity, productivity, trade and social development. For a developing country like Nigeria and other West African countries, effective implementation of ICT policies is a precondition to the emergence of a strong market economy" (Anie, 2011).

\subsection{Government and Infrastructural Development}

Rao \& Srinivasu (2013) theorizes that infrastructure and development complement each other. The economic development in an economy solely depends on the investment made in infrastructure. They further implied that industrialization is the key to building up a country's production ability and increased per capital income, "this 
need not refer simply to the provision of plant and machinery, but also to roads, railways, power lines, water pipes, schools, hospitals, houses and even "incentive" consumer goods such as consumer durables, all of which can contribute to increased productivity and higher living standards".

With the dwindling oil prices, increasing population, lack of diversification of income for the economy, it is practical to say it will be utterly irrational to place infrastructural development solely on the laps of the government. However, corruption and misappropriation of funds have been the bane of the lack of infrastructural development in Nigeria, with comparism to what other oil producing economies in the world have attained based on dependency on the same resources. The issue of corruption has lefts doubts in the minds of the citizens as they tend to also believe if resources are well managed, then infrastructure development should not be a herculean task for the government.

Notwithstanding, the private organizations leverage on the infrastructures provided by the government to aid their growth, supply chain management, productivity and profitability. Orji, Worika \& Nsikan (2017) stated, prioritizing and promoting infrastructural development in the manufacturing sector is crucial for economic development, with infrastructure in place productivity becomes easier and attainable from the initial stage of movement of raw material, warehousing, logistics and to the final end user. With dwindling resources, the government can no longer take up the responsibility of providing infrastructural facilities alone. They are unable to meet up with the demand to put in place sufficient physical infrastructure to meet the needs of the economy in ensuring adequate productivity (Smith, 1999). Wyman (2017) believes, we have observed how unreliable and inefficient public infrastructures have proven. This can be attributed to several factors such as poor maintenance culture and inadequate provision of funds for repairs and maintenance.

\subsection{PPP for Infrastructural Development Affecting Supply Chain Management and Productivity}

Vandenberg (2015), accedes to the fact that government can embark on private public partnership. Through this avenue, funds can be pooled together for capital intensive infrastructural projects alongside the provision of knowledgeable and technical expertise. Due diligence must be observed in the course of PPP, a structured framework must be adopted to guide, regulate and audit the activities of both parties. This is to ensure accountability and professionalism while delivering on infrastructure. According to Adu, Adepoju \& Oyeola (2019), Public- private partnership can be described as a co-operation between the public and the private sector, in which the government and the private sector jointly carry out a project on the basis of an agreed division of tasks and risks, each party retaining its own identity and responsibilities. It is a vessel used by the governments to mobilize funds and deliver what they would not have otherwise been able to provide i.e. the public infrastructure and services that the economy requires.

\subsection{Tax Incentives for Local Firms Engaged in Resolving Infrastructural Challenges Affecting Supply Chain Management and Productivity Through PPP}

However, the supply chain operations of many organizations in Nigeria suffer on a daily basis due to the lack of infrastructural facilities. According to Dangote Industries (2019), the firm lost about 25billion naira due to bad roads from the year 2017 to 2019. It appears logical to shelve some responsibilities regarding infrastructural development to the private sector. The Nigerian government has gone a step further to seek ways to promote PPP through tax reliefs for private firms that are faced with infrastructural challenges in their day to day operations and seek to provide solutions themselves. However, the federal government introduced the Infrastructure Tax reliefs schemes to promote PPP with regard to infrastructure development;

Executive Order No 007 of 2019 to be cited as the company's income tax (Road Infrastructure Development and Refurbishment Investment Tax Credit Scheme) Order 2019 (E007 or the scheme). According to this scheme the main objective is to

1. Enable the Federal Government of Nigeria to leverage on private sector funding for the construction or refurbishment of Eligible Road Infrastructure projects in Nigeria.

2. Focus on the development of the Eligible Road Infrastructure projects in an effective and efficient manner that creates value for money through private sector discipline and

3. Guarantee participants in the scheme timely and fully recovery of funds provided for the construction or refurbishment of Eligible Road Infrastructure projects in the manner prescribed by the executive order.

In addition, the Company Income Tax Act Section 34 which provides Rural Investment allowance on the following conditions stating where a company incurs capital expenditure on the provisions of facilities such as electricity, water, tarred road or telephone for the purpose of a trade or business which is located at least 20 kilometres away from such facilities provided by the government, stating the following tax relief of $100 \%$ for no infrastructure, $50 \%$ for no electricity, $30 \%$ for no water, $15 \%$ for no tarred road and $5 \%$ for no telephone.

The above is a welcomed development and we expect to see organizations whose supply chain activities are affected by infrastructure development to engage in private public partnerships and enjoy tax relief. Few organizations with supply chain management have decided to partake in this scheme by taking up projects which 
have direct impact on their supply chain management and productivity. Some listed organizations and projects developed under this scheme are listed below;

- Reconstruction of Gbagada-Apapa Oshodi Expressway by Dangote Industries and Flour Mills. Logistics (Transport Infrastructure)

- Lokogoma-Gudu Road Abuja Constructed by Prince Ebeano Supermarket.

Table 2: PPP Projects in Nigeria According to the World Bank Private Participation in Infrastructure Projects (PPI)

\begin{tabular}{|l|l|l|}
\hline $\begin{array}{l}\text { Supply Chain } \\
\text { Components }\end{array}$ & Infrastructure & PPP Projects \\
\hline \multirow{5}{*}{ Logistics } & $\begin{array}{l}\text { Development of the Murtala Muhammed Airport 2 through } \\
\text { concession with Bi-Courtney Limited which involved the design, } \\
\text { construction and operation of a new domestic terminal and } \\
\text { ancillary facilities following the destruction of the old terminal in } \\
\text { a devastating fire in 2000. }\end{array}$ \\
\hline $\begin{array}{l}\text { Lekki Deep Sea Port Phase 1 is a multi-purpose, Deep Sea Port at } \\
\text { the heart of the Lagos Free Trade Zone, West African region and } \\
\text { is led by a consortium of Tolaram Group, China Harbour } \\
\text { Engineering Company, Nigerian Ports Authority and Lagos State } \\
\text { Government. }\end{array}$ \\
\hline Productivity & $\begin{array}{l}\text { Azura-Edo Gas-Fired Power Plant Phase 1 is a 461MW Open } \\
\text { Cycle Gas Turbine power station near Benin City in Edo State, } \\
\text { Nigeria. It is Phase 1 of a 1,500MW IPP facility located on a 100- } \\
\text { hectare site, large enough to accommodate future expansion of the } \\
\text { power plant. }\end{array}$ \\
\hline Infrastructure & $\begin{array}{l}\text { Nigeria Telecommunication Divestiture Ltd, handled by Transcorp } \\
\text { Corporation in order to transform NITEL into a wireless and } \\
\text { broadband player. }\end{array}$ \\
\hline
\end{tabular}

\section{Methodology}

\subsection{Research Design}

The survey research method was adopted for the purpose of this study. Online survey was forwarded to a particular sample size. The idea behind this was to ensure the opinion and perspective of the public were captured and analyzed based on the individual components of the topic.

\subsection{Sources of Data, Sampling Size and Treatment of Data}

Primary data was generated through the use of an online survey for the purpose of this research. The sample size was selected from the average Nigerian mostly in the corporate environment. Questions were presented in a simplified format for easy understanding and less ambiguity.

\subsection{Data Analysis}

Online Survey was the main medium for data collection. Based on the online survey tool used, a substantial part of the quantitative data required no conversion while qualitative analysis was utilized to explain the results from the various data presentations.

\subsection{Hypothesis and Research Question}

Literature has evidenced the underdevelopment in infrastructural facilities affecting supply chain management. However, we need to ascertain if the private sector intervention is required. Below are the research questions to validate this assertion;

1.Infrastructural development is the sole responsibility of the government.

2. Infrastructural development is too large for the government to fund independently.

3. Private sector organizations benefit from the infrastructural facilities provided by the government in an economy for their supply chain management and productivity.

4. Government should engage in promoting infrastructural development through private public partnership to enhance Private organizations supply chain management and productivity.

5. Improvement of infrastructural facilities through public private partnership would help develop the economy and supply chain management.

6. Development and improvement of infrastructural facility through private public partnership would reduce the price of goods and services.

Ho: PPP is not needed in developing public infrastructure to enhance Supply chain management and productivity. 
H1: PPP is required in developing and improving public infrastructure to enhance Supply chain management and productivity.

\subsection{Presentation of Data and Result}

Online survey was shared to 120 respondents, but only 100 usable responses were recorded representing a completion rate of about $83 \%$. See table below for respondent data chart.

\subsection{Validity of Data}

Table 3. Respondent's demography

\begin{tabular}{|l|l|l|}
\hline Gender & No of Respondents & Percentage \% \\
\hline Male & 66 & $66 \%$ \\
\hline Female & 34 & $34 \%$ \\
\hline Total no of respondents & 100 & $100 \%$ \\
\hline
\end{tabular}

\subsection{Discussion}

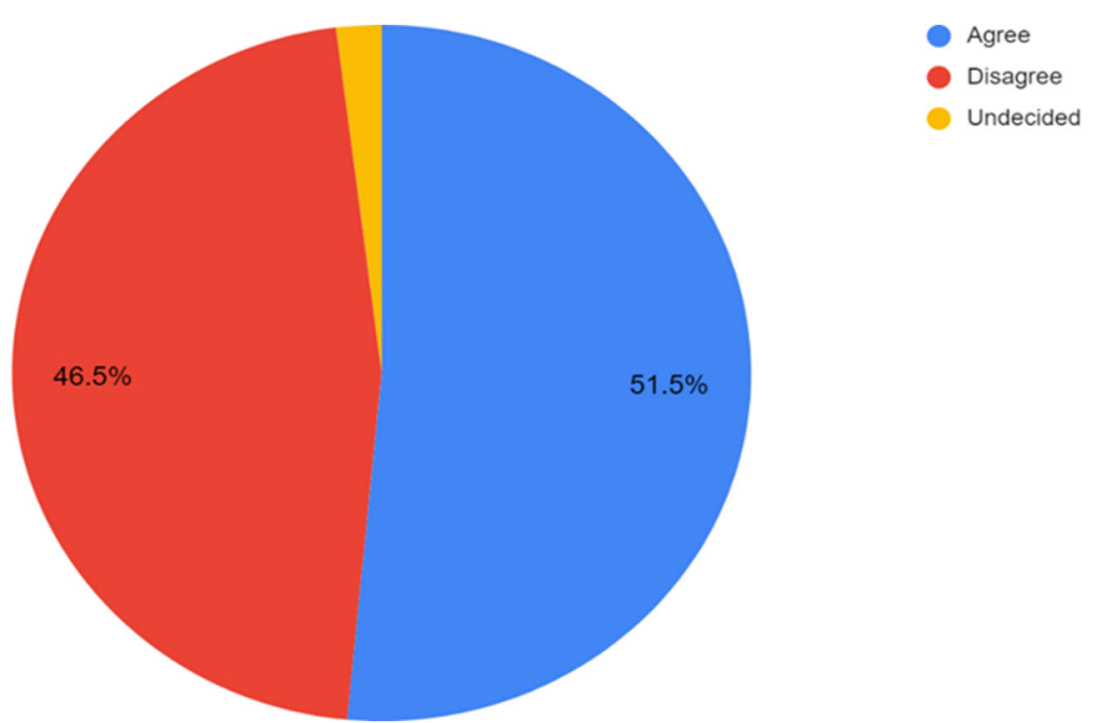

- Figure 1. Infrastructural development is the sole responsibility of the government

The result clearly shows the public is divided over this issue. $51.5 \%$ agreed that infrastructural development was too large for the government to fund, $46.5 \%$ clearly disagreed while $2 \%$ remain undecided. Multiple parties should be involved in the ownership of infrastructural facilities since it is a shared facility that is made use of by various stakeholders (Janssen, Soon and Gil-Garcia, 2009).

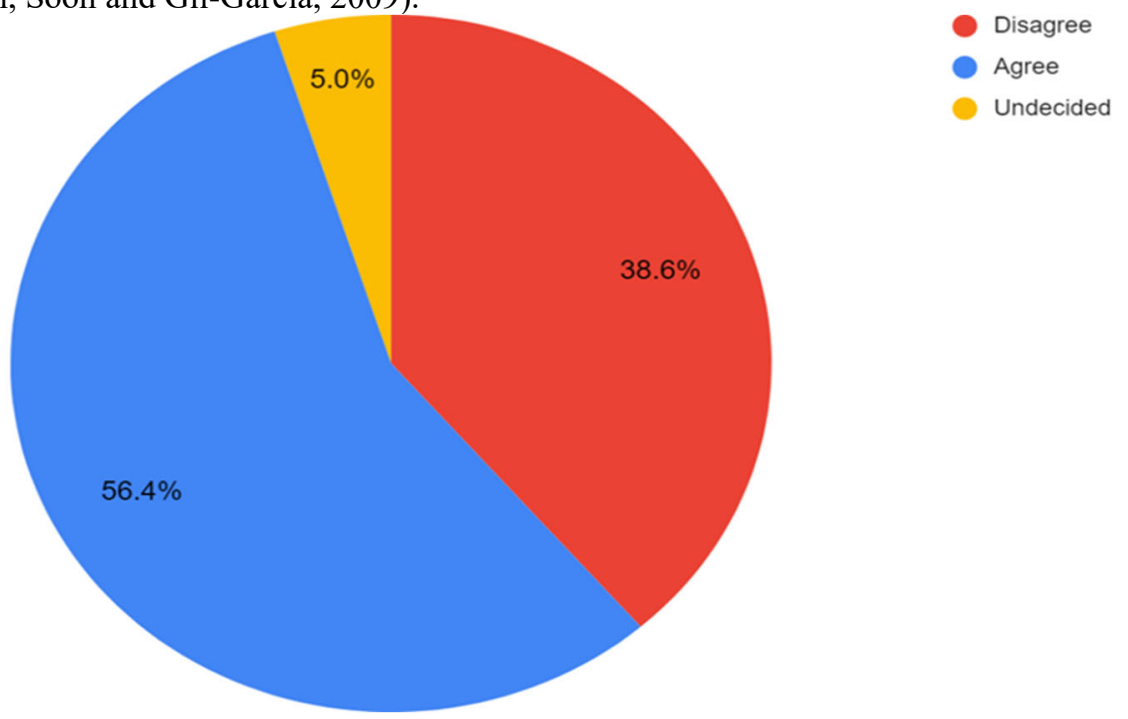

Figure 2. Infrastructural development is too large for the government to fund independently

This synchronises with the analysis from Figure 1 and further validates the credibility of the respondents. Again, it is a close call with $56.4 \%$ confirming funding too large for the government, $38.6 \%$ disagree and $5 \%$ are unable 
to come to a conclusion. Yielding to demands for new infrastructure and improvement on existing ones in order to enhance economic productivity, the government has found succour in private-public partnerships (Araujo \& Sutherland, 2010).

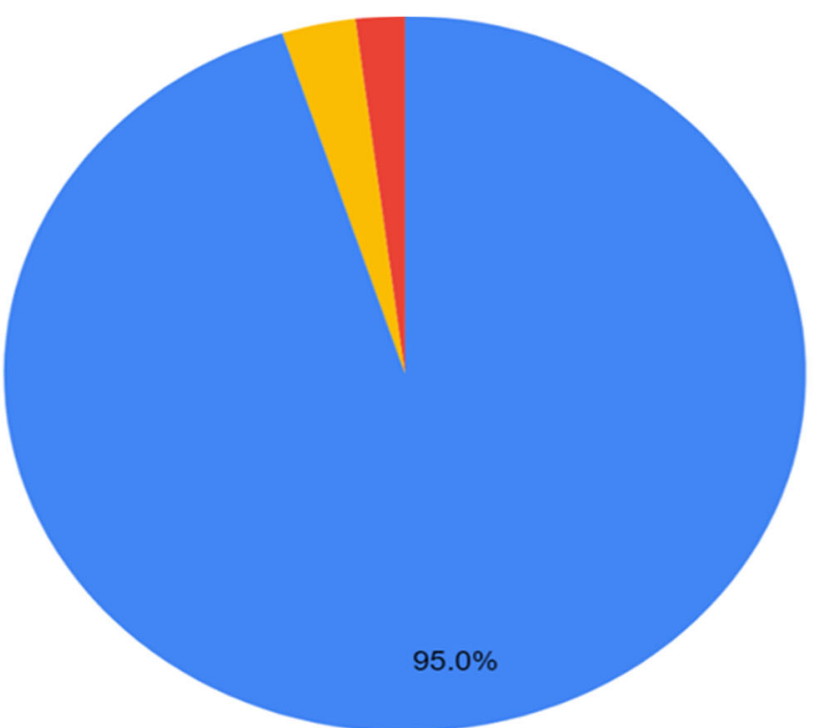

Agree

Undecided

Disagree

Figure 3. Private sector organizations benefit from the infrastructural facilities provided by the government in an economy for their supply chain management and productivity.

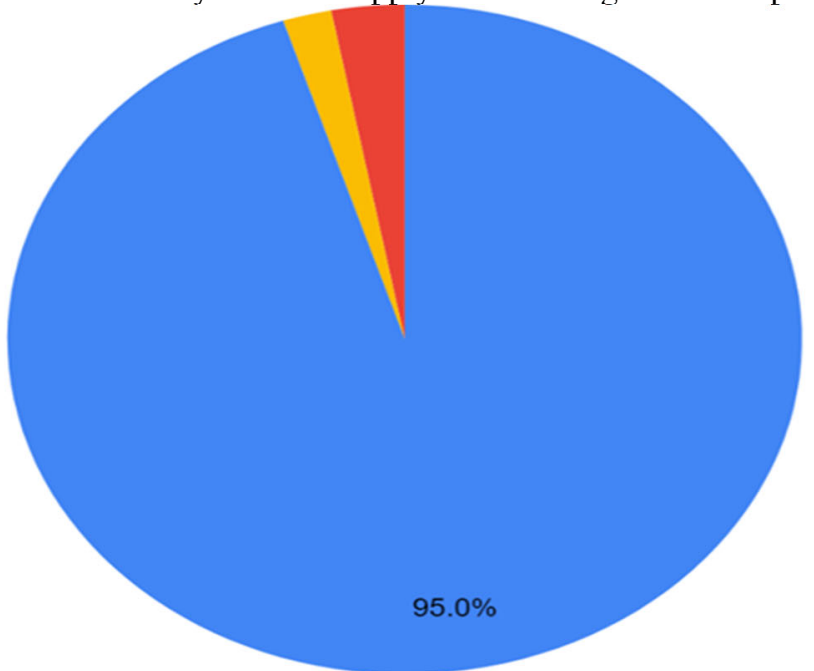

Agree
Undecided

Disagree

Figure 4. Government should engage in promoting infrastructural development through private public partnership to enhance Private organizations supply chain management and productivity.

Analyzing the result from Figure 3 and 4, 95\% believe that organizations benefit from government infrastructures in their supply chain management and productivity and agree that the government needs to engage further in PPP. This confirms the theory of the need that PPP is required for further development and improvement of public infrastructural development to enhance supply chain management and productivity. Question 3-4, the test result obviously lends credibility to $\mathbf{H 1}$. 


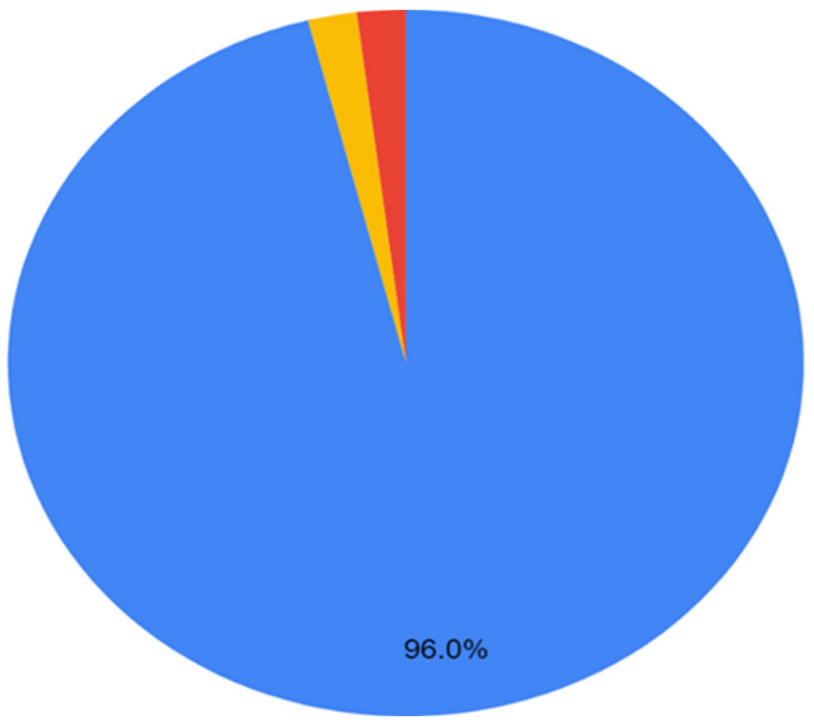

Figure 5. Improvement of infrastructural facilities through public private partnership would help develop the economy and supply chain management.

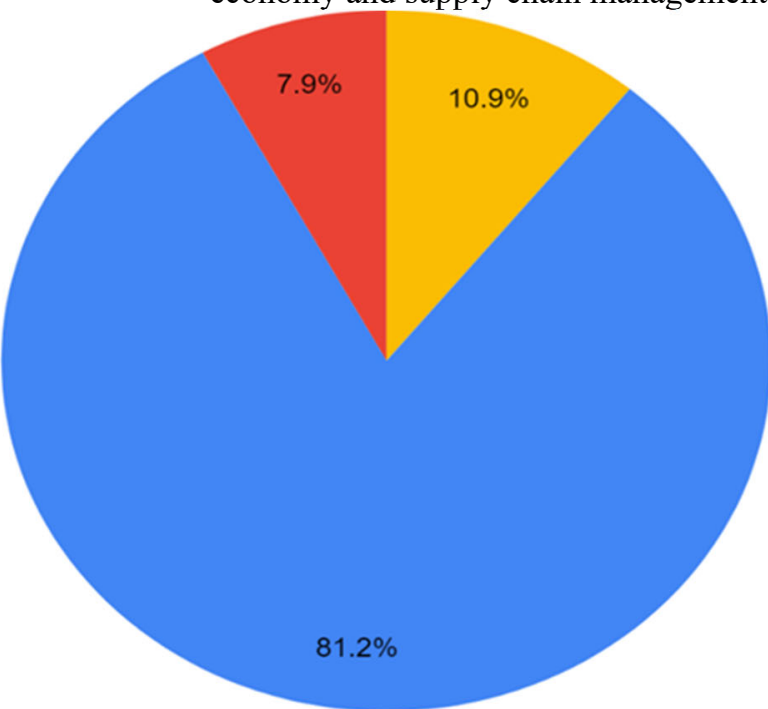

Undecided

Agree

Disagree

Figure 6. Development and improvement of infrastructural facility through private public partnership would reduce the price of goods and services.

Summarizing figures 5 and 6 , the majority are of the opinion that focusing on the development and improvement of infrastructure would help develop the economy, enhance supply chain management and productivity and further reduce the prices of goods and services. The quality of infrastructure built via PPP has been ascertained to be more effective because most PPP's are on a build, maintain and operate basis thereby producing the best service quality (Engel, Fischer \& Galetovic, 2011). Top notch quality infrastructure makes the supply chain management a seamless process and reduces the operating expense which has a direct impact on prices of goods and services.

\subsection{Conclusion and Recommendation}

The survey highlights the division amongst the people whether Public infrastructure is the sole responsibility of the government and if it's too large for them to fund. However, findings further reveal the Government needs to promote PPP further as this the opinion of most of the respondents, to enhance the productivity and supply chain management of private organizations. It is also highly recommended that organizations drive loss reduction, operating expense reduction and increase productivity through utilizing the tax incentive schemes provided by the government to develop infrastructural facilities affecting their supply chain and productivity through PPP arrangements.

\section{References}

Adhikary, M. \& Khatun, M. (2017). 'Infrastructural Development: An Engine of Growth - An Empirical Study in SAARC Countries', Handbook of Research on Economic, Financial, and Industrial Impacts on Infrastructure 
Development, pp. 1-22.

Ado, A. \& Mallo, M.J. (2015). 'Impact of Deficient Electricity Supply on the Operations of Small-Scale Businesses in North East Nigeria'. International Journal of Business and Economic Development Vol. 3(1). pp.20-30.

Adu, D., Adepoju, B., \& Oyeola, A. (2019). 'Nigeria: Public-Private Partnerships: The Prospects for Standard Infrastructural Developments in Nigeria'. Mondaq. https://www.mondaq.com/nigeria/governmentcontracts-procurement-ppp/789438/public-private-partnerships-the-prospects-for-standardinfrastructural-developments-in-nigeria

Anie, S.O. (2011). 'The Economic and Social Benefits of ICT Policies in Nigeria'. Library Philosophy and Practice, pp. 125.

Araujo, S. \& Sutherland, D. (2010), 'Public-Private Partnerships and Investment in Infrastructure', OECD Economics Department Working Papers No. 803. pp.1-41.

Chaitangjit, P. \& Ongkunaruk, P. (2019). 'The Study of Cold Storage and Temperature Controlled Transportation': A Case Study of a Chain Restaurant in Thailand. Pamukkale University Journal of Engineering Sciences. Vol. 25(9). pp. 1014-1019.

Christopher, M. (2016). 'Logistics and Supply Chain Management', The fifth Edition. Pearson Education, pp.1310.

Companies Income Tax (Last reviewed December 2007) COMPANIES INCOME TAX ACT CAP. 60 L.F.N. 1990 ACT CAP. C21 L.F.N. 2004

Dangote Group (2019). 'The Apapa-Oshodi road will last for 40 years when completed'. https://angotegroup.africa-newsroom.com/press/the-apapaoshodi-road-will-last-for-40-years-when-completed-dangote

Emeasoba, U.R.B \& Ogbuefi ,J.U. (2013) 'Sustainable Socio-Economic Development In Nigeria: A Case For Road Infrastructure Maintenance', Journal of Environment and Earth Science Vol. 3(5) pp.129-137.

Engel, E., Fischer, R., and Galetovic, A. (2011). 'Public-Private Partnerships to Revamp U.S. Infrastructure' The Hamilton Project. pp.1-8.

Executive Order 7 Of 2019 On The Road Infrastructure Development And Refurbishment Investment Tax Credit Scheme.

Fourie, J. (2006). 'Economic Infrastructure: A Review of Definitions, Theory and Empirics', South African Journal of Economics Vol (74)3, pp.531-532.

Janssen, M., Soon, A.C, \& Gil-Garcia, J.R. (2009). 'Building the next generation of digital government infrastructures' Government Information Quarterly, Vol26(2). pp. 233-237.

Lambert, D. \& Cooper, M. \& Pagh, J. (2000). 'Supply Chain Management: Implementation Issues and Research Opportunities', International Journal of Logistics Management, Vol 29 (1), pp.65-83.

Lummus, R., krumwiede, D.W., \& Vokurka, R.J. (2001),' The relationship of logistics to supply chain management: developing a common industry definition'. 2001 Industrial Management \& Data Systems, Volume 101(8), pp.426-431.

Mentzer, J., Dewitt, W., Keebler, J., Min, S., Nix, N., Smith.C., \& Zacharia, Z. (2001). 'Defining Supply Chain Management', Journal of Business Logistics, Vol 22(2) pp.1-25.

Moyo, B. (2013). 'Power infrastructure quality and manufacturing productivity in Africa: A firm level analysis', Energy Policy, Vol 61, pp. 1063-1070.

Olayemi, S.O. (2012). Electricity Crisis and Manufacturing Productivity in Nigeria (1980-2008). Developing Country Studies, Vol (2), pp. 16-21.

Orji, K. Worika, I., \& Umofia, N. (2017). 'The Impact of Infrastructural Development on Nigeria's Industrial Sector'. African Research Review. Vol.11(3). pp. 23-30.

Oyesiku, O., Somuyiwa, A., \& Oduwole, A. (2020).' Analysis of Transport and Logistics Education Regulations and Economic Development in Nigeria'. Transportation Research Procedia. Vol.48. pp.2462-2487.

Posu, S.M.A. (2006). 'Information and Communication Technologies in the Nigerian Economy'. International Conference on Human and Economic Resources, Izmir, pp.327-337.

Ramaa, A., Subramanya, K.N., \& Rangaswamy, T.M. (2012). 'Impact of Warehouse Management System in a Supply Chain', International Journal of Computer Applications (0975 - 8887) Vol. 54(1) pp. 14-20.

Rao, P.S., \& Srinivasu, B. (2013). 'Infrastructure Development and Economic growth': Prospects and Perspective. Journal of Business Management \& Social Sciences Research, Vol. (2), pp. 81-91.

Rietveld, P. (1989). 'Infrastructure and Regional Development(A survey of multi-regional economic models)' The Annals of Regional Science vol (23), pp.255-274.

Sharma, C., \& Sehgal, S. (2010). Impact of infrastructure on output, productivity and efficiency: Evidence from the Indian manufacturing industry. Indian Growth and Development Review, Vol (3), pp. 100-121.

Smith, A. J. (1999). 'Privatized Infrastructure, The role of government'. Institute of Civil Engineers Publishers.pp.1-241.

Stainer, A. and Stainer, L. (1997), 'Productivity and performance dimensions of corporate communications 
strategy', Corporate Communications: An International Journal, Vol. 2 (2), pp. 70-75.

Tangen, S. (2002). 'Understanding the concept of productivity', Proceedings of the 7th Asia Pacific Industrial Engineering and Management Systems Conference, pp .4-8.

Tseng, Y.Y., Yue, W. \& Taylor, M. (2005). 'The role of transportation in logistics chain'. Proceedings of the Eastern Asia Society for Transportation Studies. Vol (5). 1657-1672.

Urowayino, J. (2020, September 11). Manufacturers spent 38\% production cost on power in 2019. Vanguard Newspaper. https://www.vanguardngr.com/2020/09/manufacturers-spent-38-production-cost-on-power-in2019/

Vandenberg, P. (2015). 'Engaging the Private Sector in Public-Private Partnerships ADB Institute'. Vol 4. pp. 18.

World bank, (2020). Private Participation in https://ppi.worldbank.org/en/snapshots/country/nigeria

Wyman, O. (2017). 'Bridging the infrastructure gap: engaging the private sector in critical national development benefits, risks and key success factor’. pp. 1-24. 